Anatolian Journal of Education

\title{
CAUSES OF PREMARITAL SEX AS EXPRESSED BY ADOLESCENTS IN YAGBA WEST, KOGI STATE, NIGERIA
}

\author{
Lateef Omotosho Adegboyega* \\ Department of Counsellor Education, Faculty of Education, University of Ilorin, Ilorin, \\ Nigeria, adegboyega.lo@unilorin.edu.ng \\ Olumayowa Ayorinde Jacob \\ Department of Social Sciences Education, Faculty of Education, University of Ilorin, \\ Ilorin, Nigeria
}

\begin{abstract}
Pre-marital sex is sexual intercourse engaged in by persons who are not married to each other. This study therefore investigated causes of premarital sex as expressed by adolescents in Yagba West, Kogi State. This study adopts descriptive survey research type. The population for the study was all the secondary school students (adolescents) in Yagba West, Kogi State. A researchers-designed questionnaire was used to collect the data for the study. In analyzing the data collected mean rating was used to answer the research question. All the null hypotheses generated for the study were tested using the independent t-test method of statistical analysis at 0.05 level of significance. Finding revealed that main cause of premarital sex among Secondary School students in Yagba West, Kogi State was that enticement by wealthy individuals lure adolescents into premarital sex. Furthermore, it was discovered from the study that there is no significant difference in the opinion of secondary school students on causes of premarital sex on the basis of gender, religion and age. It was recommended that educational psychologists and counsellors as a first step have the task of demystifying sexuality by providing the youngsters with adequate and relevant information regarding sexuality and reproductive health.
\end{abstract}

Keywords: Adolescents, Causes, Premarital Sex, Yagba West, Kogi State.

\footnotetext{
* Adegboyega, Lateef Omotosho, Department of Counsellor Education, Faculty of Education, University of Ilorin, Ilorin, Nigeria

E-mail: adegboyega.lo@unilorin.edu.ng
} 


\section{Introduction}

Pre-marital sex is sexual intercourse engaged in by persons who are not married to each other. It is generally used in reference to individuals who are presumed not yet of marriageable age, or between adults who will presumably marry eventually, but who are engaging in sexual activity prior to marriage (Lucas, 2000; Barbra, Sprecher, Treger, \& Sakaluk, 2001; Ramesh, 2008). Pre-marital sex is sex before marriage and it is generally found among the youths. It involves fornication, rape, defilement and incest. The causes behind it have been established including curiosity among the youth, proof of manhood, lust, pornography and its adverse effects, insanity and sex promiscuity as well as moral decadence among the youths (Choe, Hatmadji, Podhisita, Raymundo \& Thapa, 2004).

Worldwide, rates of sexually transmitted diseases (STDs) among the youth are soaring: one-third of the 340 million new STDs each year occur in people under 25 years of age (Fernández-Villaverde, Jeremy \& Nezih, 2010). Each year, more than one in every 20 youth contracts a curable STDs. More than half of all new HIV infections occur in people between the ages of 15 to 24 years. The sexual health needs for adolescent girls who are generally overlooked, stigma and vulnerability affects particular groups of men as well as women (Kiragu \& Zabin, 1993).

According to the National Synthesis Report on the district initiative on HIV/AIDS action in the year 1995, its was found that between the ages of 13 and 19 years of all the school going age, $62 \%$ were females and $48 \%$ were males who were sexually active. Much as the figure in 2000-2001 deflated from 52\% and 39\% respectively, it is reportedly so much happening and evident in the sub-Saharan Africa (Lucas, 2000). For instance, a study by Ramesh (2008) found that one third of the students (39\%) had premarital sex. However, youths are still practicing pre-marital sex and thus they share the blame and responsibility in the spread of HIV/AIDS increase.

The HIV/AIDS epidemic is the world most deadly undeclared war and Africa gave birth to its brant (Dittus \& Jacard, 2000). According to UNICEF (1998), in Africa where some 200,000 lives were lost as a result of conflict and war, AIDS killed 2.2 million people. The disease now is the leading killer. In sub-Saharan Africa, it has killed 16.3 million lives since the epidemic began. Pre-marital sexual intercourse has of recent developed a major concern among the adolescents.

It is basically on the above background that the youths have suffered a lot from the HIV/AIDS scourge and its infections have become a serious threat among the youths and this has shortened the life span of the youths. High levels of premature birth with an increasing level of infant mortality rate, it is not known how much of the various means of spread of HIV is due to pre-marital sex, and this study set out to find out the role it plays in the spread of HIV.

There has always been education by the different cultures on the preventive measure to HIV/AIDS in Nigeria and Kogi State in specific. This has been in terms of education countrywide to change the moral behaviours of the youths in the religious community, 
schools and in the military. This has been done in promoting abstinence until marriage and then faithfulness within the married people (Akinkunmi, 1999).

Among the youths today, the introduction to use condoms has increased the act of premarital sex because they are believed to protect them from harmful diseases like HIV/AIDS. This has enticed many youths in Nigeria and Kogi State specifically to engage themselves in the act, yet condoms are not 100 percent safe to protect against the disease. Due to sensitivity of this issue, youths receive inadequate education, guidance and services on the dangers of premarital sex. This led the researchers to seek information on the issues regarding the causes of premarital sex in the spread of HIV/AIDS among adolescents in Yagba West, Kogi State, Nigeria.

There are many behavioural problems among the adolescents that Nigerian society today has to contend with. Such problems include truancy, disobedience, drug offences, assault, insult, stealing, violent demonstrations, vandalism, examination malpractices, robbery, and secret cult activities (Nnachi, 2003). Apart from these widely publicized behavioural problems, heterosexual activities are also listed among types of behavioural problems prevalent in Nigerian secondary schools. These are variously named in the literature as sex abuse, sex offences, sexual misconduct, sexual immorality, sexual promiscuity, and sexual maladjustment (Odoemelam, 1996; Adedipe, 2000; Ndu, 2000; Nnachi, 2003). The rise in premarital sex in Africa has resulted from a sexual revolution that came with western culture (Scott, 2005).

Public opinion polls have consistently shown that premarital sex is wrong and dangerous to health, resulting in abortions, teenage mothers and sexually transmitted infections (Aaron, 2006; Finer, 2007). Children learn the important topic of sex education in negative manners, rather than having proper sex socialization at home or in schools. The school authorities blame parents for children's deviant behaviours, because as the home is the first point of social contact, it is expected to have shaped the adolescents' behaviour (Isangedighi, 2007). Hence, whatever behaviour the adolescents manifest is seen to be a reflection of home upbringing (Akinkunmi, 1999). Okonkwo (2004) observed that today's situation shows a sharp contrast to the traditional Nigerian societal context in which boys and girls avoided pre-marital sexual experiences for fear of social punishments usually meted out to girls who lost their virginity before marriage.

Early sexual debut is known to increase the risks of teenage pregnancy, maternal and paternal mortality, and sexually transmitted infections (STIs), including HIV (Thomson \& Coletta, 1992). HIV/AIDS prevention campaigns have identified premarital sex behaviour as one of major risky behaviours among youths (Smith, 2004; Cheluget, Baltazar, Orege, Ibrahim, Marum, \& Stover 2006; Kirungi, Musinguzi, Madraa, Mulumba, Calleja, Ghys \& Bessinger, 2006; Mahomva, Greby, Dube, Mugurungi, Hargrove \& Rosen, 2006). Comparatively, little is known about what mechanisms shape premarital sex behaviours among youths (Campbell, 2003) and even less in the context of Nigeria. 
In a study by Westera and Bennett (1994) $88 \%$ of high school males and $84 \%$ of females expressed attitudes supportive of premarital sexual behaviours. In addition, it has been reported that the number of adolescents engaging in premarital sex has increased to $63 \%$ in the last 20 years (Martin, Martin \& Martin, 2001). As reported by Feigenbaum, Weinstein and Rosen (1995) in premarital sexual activity and attitude towards marriage a sample of college undergraduates reported that $69.9 \%$ of males and $59.5 \%$ of females engaged in premarital sex by the age of 17 (Martin, Martin \& Martin, 2001).. Therefore individuals are increasingly engaging in traditionally high risk premarital behaviours, behaviours that increase their chances of marital instability, yet their desire for a happy marriage prospers (Popenoe \& Whitehead, 2000).

However, much has not been done in the area of causes of premarital sex as expressed by adolescents in Yagba West, Kogi State. Recognizing the growing consequences of premarital sex among adolescents, this study is an attempt to contribute to an understanding of the causes of premarital sex in Yagba West, Kogi State. To further understand the causes of premarital sex among adolescents, this study also seeks to explore and explain the roles of the gender, religion and age that is, which of the moderating variables would have a significant influence on the causes of premarital sex among adolescents in Yagba West, Kogi State, Nigeria.

\section{Purpose of the Study}

The general purpose of this study was to examine the causes of premarital sex as expressed by adolescents in Yagba West, Kogi State.

Specifically, this study examined:

1. the difference in the opinion of secondary school students (adolescents) on causes of premarital sex on the basis of gender.

2. the difference in the opinion of secondary school students (adolescents) on causes of premarital sex on the basis of religion.

3. the difference in the opinion of secondary school students (adolescents) on causes of premarital sex on the basis of age.

\section{Research Questions}

The following research questions were raised to guide the conduct of this study:

1. What are the causes of premarital sex as expressed by adolescents in Yagba West, Kogi State?

2. Is there any difference in the opinion of secondary school students (adolescents) on the causes of premarital sex on the basis of gender?

3. Is there any difference in the opinion of secondary school students (adolescents) on the causes of premarital sex on the basis of religion?

4. Is there any difference in the opinion of secondary school students (adolescents) on the causes of premarital sex on the basis of age? 


\section{Research Hypotheses}

The following null hypotheses were formulated and tested in the study:

Ho$_{1}$ : There is no significant difference in the opinion of secondary school students (adolescents) on causes of premarital sex on the basis of gender.

Ho$_{2}$ : There is no significant difference in the opinion of secondary school students (adolescents) on causes of premarital sex on the basis of religion.

$\mathrm{Ho}_{3}$ : There is no significant difference in the opinion of secondary school students (adolescents) on causes of premarital sex on the basis of age.

\section{Method}

This study adopts descriptive survey research type. The population for the study was all the secondary school students (adolescents) in Yagba West, Kogi State. The target population for the study was all senior secondary school students (SSS III) in randomly selected secondary schools. Ten (10) secondary schools were selected from Yagba West, Kogi State using dip-hat sampling method. The dip-hat sampling method is a method where by the researcher writes the names of the samples to be possibly selected on different sheets of papers, puts them in a bag, shakes them and then dip his/her hand into the bag to pick a sample. Twenty (20) students were selected each from the 10 schools using stratified random sampling technique across the selected schools. A total number of 200 respondents were finally selected for this study. The stratification was based on gender.

Researchers-designed questionnaire was used as an instrument to elicit the needed information for this study.

In order to ascertain the validity of the instrument, the draft of the questionnaire was given to five lecturers in the Department of Counsellor Education, University of Ilorin for vetting and advice. Sequel to their suggestions, necessary amendments were made.

The reliability of the instrument was ascertained using the test re-test reliability method. The instrument was administered to a group of twenty (20) students in Kogi State, who do not form part of the respondents for the study and after an interval of four weeks; the same instrument was re-administered to the same group of people. The two sets of scores were correlated using the Pearson Product Moment Correlation formular. The correlation co-efficient obtained was 0.72 . Based on this, the instrument was adjudged reliable for the study.

In analyzing the data collected, percentage was used to analyze the demographic data of the respondents and mean rating was used to answer the research question. All the null hypotheses generated for the study were tested using the independent $\mathrm{t}$-test and Analysis of Variance (ANOVA) method of statistical analysis at 0.05 level of significance. 


\section{Findings}

Research Question 1: What are the causes of premarital sex as expressed by adolescents in Yagba West, Kogi State?

Table 1

Ranking Order of Causes of Premarital Sex as Expressed by Adolescents in Yagba West, Kogi State

\begin{tabular}{|c|c|c|c|}
\hline No & The cause of premarital sex is that: & Mean & Ranking \\
\hline 1. & Some youth engage in sex before marriage because of having so strict parents & 2.53 & $\overline{5}^{\text {th }}$ \\
\hline 2. & Some youth engage in premarital sex due to peer pressure & 2.07 & $17^{\text {th }}$ \\
\hline 3. & $\begin{array}{l}\text { Having close friends who are married influence youth to engage in premarital } \\
\text { sex }\end{array}$ & $\overline{2.39}$ & $\overline{9^{\text {th }}}$ \\
\hline 4 & $\begin{array}{l}\text { Youth from poor family backgrounds likely to engage in premarital sex } \\
\end{array}$ & 1.67 & $21^{\text {st }}$ \\
\hline 5 & Youth who are neglected by parents engage in premarital sex & $\overline{1.98}$ & $\mathbf{1 8}^{\text {th }}$ \\
\hline 6 & $\begin{array}{l}\text { The educational background of the youth's parents influence him/her to } \\
\text { engage in premarital sex }\end{array}$ & $\overline{1.81}$ & $\overline{19^{\text {th }}}$ \\
\hline 7 & The youth in school also engage in premarital sex & 2.52 & $6^{\text {th }}$ \\
\hline 8 & Some youths are forced to engage in premarital sex & $\overline{2.37}$ & $\overline{8^{\text {th }}}$ \\
\hline 9 & I received sex education at some point in my schooling. & 2.11 & $15^{\text {th }}$ \\
\hline 10 & I often feel pressure to engage in sexual intercourse. & 2.30 & $12^{\text {th }}$ \\
\hline 11 & I think sex before marriage is absolutely acceptable & $\overline{1.43}$ & $\mathbf{2 3}^{\text {rd }}$ \\
\hline 12 & My female/male friends think sex before marriage is absolutely acceptable. & 1.56 & $22^{\text {nd }}$ \\
\hline 13 & Most of my sexual knowledge came from parent(s) & 2.33 & $\mathbf{1 0}^{\text {th }}$ \\
\hline 14 & The existence of covetousness and desire for wealth causes premarital sex & 2.52 & $6^{\text {th }}$ \\
\hline 15 & $\begin{array}{l}\text { Breakdown in the cultural norms guiding sexual conduct is responsible for } \\
\text { the prevalence of premarital sex among adolescents }\end{array}$ & $\overline{2.18}$ & $\mathbf{1 3}^{\text {th }}$ \\
\hline 16 & Poverty is one of the major cause of campus premarital sex & 1.84 & $20^{\text {th }}$ \\
\hline 17 & Degeneration of cultural values causes adolescents premarital sex & 1.91 & $\overline{19^{\text {th }}}$ \\
\hline 18 & Sexual advance from teachers leads to premarital sex among the adolescents & 2.71 & $3^{\text {rd }}$ \\
\hline 19 & Indecent dressing among female students promotes premarital sex & 2.59 & $4^{\text {th }}$ \\
\hline 20 & Enticement by wealthy individuals lure adolescents into premarital sex & $\overline{3.76}$ & $\mathbf{1}^{\text {st }}$ \\
\hline 21 & Dereliction of parental role leads to premarital sex among adolescents & $\overline{3.41}$ & $2^{\text {nd }}$ \\
\hline 22 & $\begin{array}{l}\text { Advent of Mobile phone and Social networks such as facebook, blackberry } \\
\text { messenger, Youtube promotes desire for sex among adolescents }\end{array}$ & 2.31 & $11^{\text {th }}$ \\
\hline 23 & $\begin{array}{l}\text { Rigidity of some religious organization and Parents on the issue of sex } \\
\text { education leads female students to sex-trade. }\end{array}$ & 2.11 & $15^{\text {th }}$ \\
\hline
\end{tabular}

Table 1 indicates that 200 respondents participated in this study. The major cause of premarital sex among secondary school students in Yagba West, Kogi State was that enticement by wealthy individuals lure adolescents into premarital sex which has a mean 
score of $3.76\left(1^{\text {st }}\right)$, while dereliction of parental role leads to premarital sex among adolescents with a mean score of 3.41 came $2^{\text {nd }}$, sexual advance from teachers leads to premarital sex among the adolescents which has a mean score of 2.71 was ranked $\left(3^{\mathrm{rd}}\right)$, indecent dressing among female students promotes premarital sex which has a mean score of 2.59 was ranked $\left(4^{\text {th }}\right)$, some youths engage in sex before marriage because of having so strict parents which has a mean score of 2.53 was ranked $\left(5^{\text {th }}\right)$. Other statements have mean score below the benchmark of 2.50 .

$\mathbf{H}_{\mathrm{O} 1}$ : There is no significant difference in the opinion of secondary school students (adolescents) on causes of premarital sex on the basis of gender.

In order to test this hypothesis, opinion of secondary school students (adolescents) on causes of premarital sex based on gender were collated. The output of the analysis reveals thus:

Table 2

The t-test Analysis of Opinion of Secondary School Students (Adolescents) on Causes of Premarital Sex Based on Gender

\begin{tabular}{|c|c|c|c|c|c|c|c|}
\hline Gender & $\mathbf{N}$ & Mean & Std. & $\begin{array}{l}\text { Cal. t- } \\
\text { Value }\end{array}$ & df & Sig. (2-tailed) & Decision \\
\hline Male & 98 & 52.10 & 9.55 & & & & $\mathbf{H}_{01}$ \\
\hline & & & & 0.54 & 198 & 0.59 & Not \\
\hline Female & 10 & 51.41 & 8.41 & & & & Rejected \\
\hline
\end{tabular}

Results on table 2 shows a t-value of 0.54 and a p-value of $0.59 \geq 0.05$ alpha level of 0.05 . Since 0.59 is greater than 0.05 alpha level, hence the hypothesis is not rejected. This indicates that there is no significant difference in the opinion of secondary school students (adolescents) on causes of premarital sex on the basis of gender.

$\mathbf{H}_{\mathbf{O} 2}$ : There is no significant difference in the opinion of secondary school students (adolescents) on causes of premarital sex on the basis of religion.

In order to test this hypothesis, opinion of secondary school students (adolescents) on causes of premarital sex based on religion were collated. The output of the analysis reveals thus: 
Table 3

ANOVA Showing the Opinion of Secondary School Students (Adolescents) on Causes of Premarital Sex Based on Religion

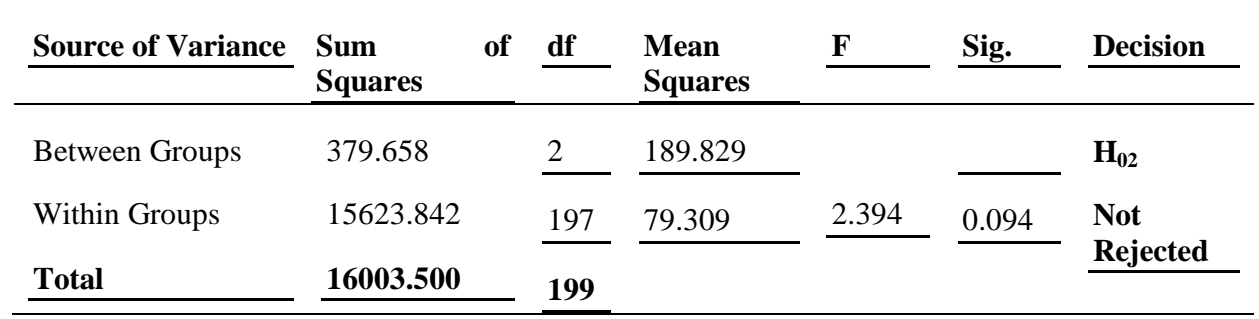

Results on table 3 shows F-value of 2.394 with p-value of $0.094>0.05$ alpha level. Since 0.094 is greater than 0.05 alpha level, hypothesis two is hereby not rejected. This indicates that there is no significant difference in the opinion of secondary school students (adolescents) on causes of premarital sex on the basis of religious affiliation.

$\mathbf{H}_{\mathrm{O3}}$ : There is no significant difference in the opinion of secondary school students (adolescents) on causes of premarital sex on the basis of age.

In order to test this hypothesis, opinion of secondary school students (adolescents) on causes of premarital sex based on age were collated. The output of the analysis reveals thus:

Table 4

ANOVA Showing the Opinion of Secondary School Students (Adolescents) on Causes of Premarital Sex Based on Age

\begin{tabular}{|c|c|c|c|c|c|c|}
\hline Source of Variance & Sum & df & Mean & $\underline{\mathbf{F}}$ & Sig. & Decision \\
\hline Between Groups & 507.496 & 3 & 189.165 & & & $\mathbf{H}_{03}$ \\
\hline Within Groups & 15496.004 & 196 & 79.061 & 2.140 & 0.097 & Not \\
\hline Total & 16003.500 & 199 & & & & \\
\hline
\end{tabular}

Results on table 4 shows F-value of 2.140 with p-value of $0.097>0.05$ alpha level. Since 0.097 is greater than 0.05 alpha level, the hypothesis is thus not rejected. This indicates that there is no significant difference in the opinion of secondary school students (adolescents) on causes of premarital sex on the basis of age. 


\section{Discussion}

Finding revealed that the major cause of premarital sex among Secondary School students in Yagba West, Kogi State was that enticement by wealthy individuals lure adolescents into premarital sex. This finding support that of Oguguo (1996) who found that peer influence is the major causes of teenage premarital sex. Albert (2007) stated that there are social pressures that push the teens toward premarital sex. Many teens engage in unhealthy activities just so that their uppers will notice them or so that they may fit in, peer pressure to engage in sexual activity is so common, a variety of terms refers to the behaviour, such as "hooking up", "booty calls" or referring to someone as a friends with benefits.

Finding revealed that there is no significant difference in the opinion of secondary school students (adolescents) on causes of premarital sex on the basis of gender. This finding is in line with that of Moore and Rosenthal (1993); McKinnon, Potter, and Garrard-Burnett (2008) and Verona and Dias Junior (2012) who found that there is no significant difference in the opinion of adolescents on causes of premarital sex on the basis of gender.

Finding revealed that there is no significant difference in the opinion of secondary school students (adolescents) on causes of premarital sex on the basis of religion. This finding is against that of Kekesi (1997) and Okonkwo (2004) who found that there was a significant difference in the opinion of adolescents on causes of premarital sex on the basis of religion. On the contrary, Mwaba and Naidoo (2005) found that been a muslim or a christian does not influence opinion of adolescents on causes of premarital sex.

Another finding revealed that there is no significant difference in the opinion of secondary school students (adolescents) on causes of premarital sex on the basis of age. This finding is in disagreement with that of Lammers, Ireland, Resnick and Blum (2000) who found that students ages 13 to 18 attitude of not initiating sex was associated with having a two-parent family and higher socioeconomic status, residing in a rural area, performing better in school, feeling greater religiosity, not having suicidal thoughts, and believing parents care and hold high expectations for their children. Finer (2007) indicated that among teenagers who did not feel close to their mother and/or father, $70.6 \%$ had sex by the age of 17 to 19 compared to $57.9 \%$ who felt close to mother and/or father.

\section{Conclusion}

Based on the findings of this study, it can be concluded that the major cause of premarital sex among secondary school students in Yagba West, Kogi State was that 
enticement by wealthy individuals lure adolescents into premarital sex. There is no significant difference in the opinion of secondary school students (adolescents) on causes of premarital sex on the basis of gender, religion and age.

\section{Recommendations/Suggestions}

Based on the findings of this study, the following recommendations were made: Considering the upsurge of teenage pregnancy, sexually transmitted diseases and HIV/AIDS, educating adolescents about sexuality requires joint effort by parents, educational psychologists, counsellors, teachers, curriculum planners and even government. Educational psychologists and Counsellors as a first step, have the task of demystifying sexuality by providing the youngsters with adequate and relevant information regarding sexuality and reproductive health. Educational psychologists and counsellors should try new strategies like counselling on proper gender role perception and abstinence to help adolescents stay away from sex until they are ready. They should also encourage the development of skills to help adolescents ward off peers who may intimidate or lure them into wrong sexual practice. Parents should be awake to their responsibility and teach certain aspects of sexuality at home so that their children will be well prepared for family life.

Students have all the necessary information about dangers of risky sexual behaviours but continue to endanger themselves by practicing unsafe sex. In order to educate these students, there is need to correct such behaviour by using therapeutic interventions that would make them unlearn the behaviour. The Health Care Unit could work together with the educational psychologists, Student Counselling Unit in changing the behaviours of such students.

It is very clear from the findings that the sexual behaviours and attitudes of students are a danger to their own lives. Therefore, it is necessary that the Health Care centre with the help of those in authority educate students about the dangers of unprotected sex and safe sex before they contract STI's and HIV/AIDS. Students themselves should be more involved than ever in designing strategies that could help them cope with pressures that they face in institutions of higher learning where some students engage in unsafe sex.

Teachers should also teach certain aspects of sexuality at school so that the adolescents will be familiar with societal expectations of their future roles as wives and husbands. The sexuality education curriculum needs to be implemented in the schools as a matter of urgency. This should be a comprehensive package that should include adolescent reproductive health and socially accepted expressions for sexual feelings. Government should promote issues of family and regulate influx of foreign films as well as monitor and censor our local films to protect our adolescents from the adverse effects of exposure to pornographic films. 


\section{References}

Aaron, N. G. (2006). Premarital sex: whose burden? Retrieved January 2008 from http://www.singaporeangle.com.

Adedipe, V. O. (2000). “The adolescent problem behaviour (ii)" Saturday Tribune, October 14th.

Akinkunmi, S. K. (1999). Religious influence on marital stability. Journal for the Scientific Study of Religion, 36(3), 382-392.

Albert, W. (2007). The president's child.

Alo, O. A. (2008). Socioeconomic determinants of unintended pregnancies among Yoruba Women of Southwest Nigeria. Int. J. Sustainab. Dev., 1(4), 145-154.

Barbra, K., Sprecher, S., Treger, S. \&Sakaluk. J. (2001). Premarital sexualstandards and sociosexuality:Gender, ethnicity, and cohort differences. Archives of Sexual Br.

Campbell, C. (2003). Letting Them Die: Why HIV/Aids Prevention Programmes Fail. Indiana University Press.

Cheluget, B., Baltazar, G., Orege, P., Ibrahim, M., Marum, L. H., \& Stover, J. (2006).

Evidence for population level declines in adult HIV prevalence in Kenya. Sexually Transmitted Infections, 82 (Suppl) 1, 21-26.

Choe, M., Hatmadji, S., Podhisita, C., Raymundo, C. \&Thapa, S. (2004). Substance use and premarital sex among adolescents in Indonesia, Nepal, the Philippines and Thailand. Asia Pac. Popul. J., 19, 5-26.

Dittus, P. \&Jaccard, J. (2000). The relationship of adolescent perceptions of maternal disapproval of sex and of the mother-adolescent relationship to sexual outcomes. Journal Adolescent Health, 26: 268 - 278.

Fernández-Villaverde, J. G. \& Nezih, G. (2010). From shame to game in one hundred years: An economic model of the rise in pre-marital sex and its de-stigmatization.

Finer, L. B. (2007). Trends in Premarital Sex in the United States, 1954-2003, Public Health Reports, 112 (6), 29-36.

Isangedighi, A. J. (2007). Child Psychology Development and Education. 1st Edn.,EtinwaAssociates, Calabar, Nigeria. pp. 107-108.

Joseph, T. (1996). The experience of teenage pregnancy in knoppleslaagte. South African Journal of Sociology, 27(30), 78-90.

Kiragu, K.\&Zabin, L. (1993). The correlates of pre-marital sexual activity among school-age adolescents in Kenya. International Family Planning Perspectives. 
Kirungi, W. L., Musinguzi, J., Madraa, E., Mulumba, N., Calleja, J. M. G., Ghys, P., \& Bessinger, R. (2006). Trends in antenatal HIV prevalence in urban Uganda associated with uptake of preventive sexual behaviour. Sex Transm Infect., 82(Suppl) 1, 36-41.

Lammers, C., Ireland, M., Resnick, M., \& Blum, R. (2000). Influences on adolescents' decision to postpone onset of sexual intercourse: A survival analysis of virginity among youths aged 13 to 18 years. The J.Adolesc. Health, 26, $42-48$.

Lucas R. (2000). Pre-marital sex, sexuality, and risk to HIV/AIDS in Addis Abeba, Ethiopia. University of Michigan, the Population Studies Center, 426 Thompson Street, United States.

Mahomva, A., Greby, S., Dube, S., Mugurungi, O., Hargrove, J., \& Rosen, D. (2006). HIV prevalence and trends from data in Zimbabwe, 1997-2004. Sexually Transmitted Infections, 82 (Suppl 1), 42-47.

Martin, P., Martin, D. \& Martin, M. (2001). Adolescent premarital sexual activity, cohabitation, and attitudes toward marriage. Adolescence, 36, 601-609.

McKinnon, S.; Potter, J. \& Garrard-Burnett, V. (2008). Adolescent fertility and religion in Rio de Janeiro, Brazil in the year 2000: The role of Protestantism. Population Studies, 62(3), 289-303.

Moore, N. \& Rosenthal, K. (1993). An exploratory study of the experiences of black teenage mother. Unpublished M.Sc. thesis, Rhodes University East London.

Mwaba, K. \& Naidoo, P. (2005). Sexual practices, attitudes toward pre-marital sex and condom use among a sample of South Africanuniversity students. SocialBehaviour and Personality: An InternationalJournal, 33(7), 651 - 656.

Nnachi, R. O. (2003). Causes, consequences and control of behaviour problems among Nigerian children" in Nnachi RO, Ezeh PSE (Eds.). (2003). Thebehaviour problems of the Nigerian Child, Awka. The Nigerian Society for Educational Psychologists (NISEP).

Odoemelam, A. (1996). Incidence and management of male and female sexually maladjusted youngsters: gender and counseling implications. The Counsellor, 14(92), $160-171$.

Oguguo, N. (1996). America's infant mortality problems: Parents. The walls stress Journal, 20, 12.

Okonkwo, M. C. (2004). Education based problems and self-concepts of secondary school teenage mothers. Unpublished Ph.D. Thesis, department of education foundations, Nnamdi Azikiwe University, Awka.

Popenoe, D. \& Whitehead, B. (2000). Sex without strings, relationships without rings: Today's young singles talk about mating and dating. A Publication of the National Marriage Project. 
Ramesh, A. \& Tgotsne T. (2009). Premarital sexual behaviours among male college students in Kathmandu. Nepal B.M.C. Public Health, 9 (2), 241.

Scott, J. (2005). Children ask the Damndest Questions: Sex (quality) Education as a Social Problem. In Perspectives in Human Sexuality, eds. G. Hawkes and J. Scott HAWKES, Victoria, Australia: Oxford University Press.

Smith, D. J. (2004). Premarital sex, procreation and HIV risk in Nigeria. Studies in Family Planning. 35(4), 223-235,

Thomson, E. \& Coletta, U. (1992). Cohabitation and marital quality and stability: Quality or commitment? Journal of Marriage and the Family, 54, 259-267.

Verona, A. P. A. \& Dias Junior, C. S. (2012). Religiãoefecundidade entre adolescents no Brasil. Rev. Panam. SaludPublica, 31(1), 25-31. 